\title{
RELIABILITAS DAN VALIDITAS SELF-COMPASSION SCALE VERSI BAHASA INDONESIA
}

\author{
Dicky Sugianto $^{1}$, Christiany Suwartono ${ }^{2}$, \& Sandra Handayani Sutanto ${ }^{1}$ \\ ${ }^{I}$ Fakultas Psikologi, Universitas Pelita Harapan, Jalan M.H. Thamrin Boulevard 1100, Lippo Village, Tangerang \\ 15811, Indonesia \\ ${ }^{2}$ Fakultas Psikologi, Universitas Katolik Indonesia Atma Jaya, Jalan Jenderal Sudirman 51, Jakarta 12930, \\ Indonesia
}

Korespondensi:

e-mail: sugianto.ad@gmail.com

\begin{abstract}
Self-compassion is a healthy attitude toward oneself which positively associated to an individual's mental health. Self-Compassion Scale (SCS) is a common instrument to measure levels of self-compassion However, to date, there is no study that evaluates the psychometric properties of the Indonesian version of SCS. This study aims to adapt the SCS into Indonesian language and to evaluate the psychometric properties of the Indonesian version of SCS. Participants in this study were 329 college students enrolled in universities in Jakarta and surrounding areas and were recruited through convenience sampling. Instrument used in this research is the Indonesian version of SCS, which we named Skala Welas Diri (SWD). The result of psychometric evaluation using confirmatory factor analysis (CFA), construct validity, and Cronbach's Alpha coefficient showed good validity and reliability of SWD. The study suggested that SWD have a similar theoretical model as SCS. The study concludes that SWD could be used as an adequate measurement of selfcompassion.
\end{abstract}

Article history:

Received 23 December 2019

Received in revised form 7 April 2020

Accepted 9 May 2020

Available online 27 May 2020

Keywords:

confirmatory factor analysis;

scale adaptation;

self-compassion;

Self-Compassion Scale

\begin{abstract}
Abstrak - Welas diri (self-compassion) merupakan sebuah sikap yang sehat terhadap diri dan berkaitan dengan kesehatan mental. Self-Compassion Scale (SCS) merupakan instrumen yang umum digunakan untuk mengukur welas diri, tetapi belum ada penelitian yang melihat kualitas psikometrik dari adaptasi SCS Bahasa Indonesia. Penelitian ini bertujuan untuk melakukan adaptasi dan uji psikometrik SCS Bahasa Indonesia. Partisipan dalam penelitian ini adalah 329 mahasiswa aktif di salah satu universitas di Jakarta dan sekitarnya yang direkrut dengan convenience sampling. Instrumen yang digunakan adalah SCS yang diadaptasi ke dalam Bahasa Indonesia dan diberi nama Skala Welas Diri (SWD). Berdasarkan hasil uji psikometrik menggunakan confirmatory factor analysis (CFA), uji validitas konstruk, dan koefisien Cronbach's Alpha, ditemukan bahwa SWD memiliki validitas dan reliabilitas yang baik, serta memiliki model teoretis yang sama dengan SCS. Disimpulkan bahwa SWD dapat digunakan sebagai skala yang mumpuni untuk mengukur welas diri.
\end{abstract}

Kata Kunci: adaptasi skala; confirmatory factor analysis; Self-Compassion Scale; welas diri 


\section{PENDAHULUAN}

Setiap orang pernah mengalami kesulitan, kegagalan, maupun penderitaan dalam hidup yang memunculkan emosi negatif (Besser \& Priel, 2011). Seseorang yang merespons kesulitan atau kegagalan dengan sikap mengkritik diri dapat merasakan emosi negatif yang berkepanjangan (Gilbert, Baldwin, Irons, Baccus, \& Palmer, 2006), di mana hal ini akan menimbulkan permasalahan kesehatan jiwa dan penyesuaian dalam hubungan sosial. Kritik diri berkaitan dengan munculnya gejala distres, depresi, kecemasan, dan kesulitan dalam membangun hubungan sosial yang memadai (Kannan \& Levitt, 2013).

Sikap yang lebih sehat ketika mengalami kesulitan dan penderitaan hidup adalah welas diri (self-compassion; Neff, 2011). Welas diri merupakan sikap sadar dan peka terhadap penderitaan yang dialami diri dan meresponinya dengan pemahaman tanpa penghakiman, penerimaan tak bersyarat, kehangatan, dan kepedulian (Cleare, Gumley, \& O'Connor, 2018; Elices dkk., 2017; Goetz, Keltner, \& Simon-Thomas, 2011; Neff, 2016). Hal ini diikuti dengan kesadaran bahwa kesulitan yang dihadapi merupakan bagian dari kehidupan manusia yang tidak sempurna dan komitmen untuk mengentaskan diri dari penderitaan (Breines \& Chen, 2012; Leary, Tate, Adams, Allen, \& Hancock, 2007). Welas diri memungkinkan seseorang untuk meregulasi emosinya ketika menghadapi penderitaan (Feldman \& Kuyken, 2011).

Welas diri berkaitan dengan kesehatan jiwa yang baik (Neff \& Seppala, 2016). Welas diri yang tinggi berkaitan dengan tingkat distres, depresi, dan kecemasan yang rendah (Soysa \& Wilcomb, 2013). Selain itu, tingkat welas diri yang tinggi juga berkaitan dengan tingkat kritik diri yang rendah (Joeng \& Turner, 2015).

Welas diri juga berkaitan dengan penyesuaian sosial yang lebih baik. Sikap berwelas diri memungkinkan seseorang untuk fokus pada orang lain ketika berhubungan sosial (Bloch, 2018). Hal ini membuat mereka merasa lebih dekat dengan orang lain (Bloch, 2018), di mana hal ini menjadikan mereka merasa tidak kesepian dan terasing dari lingkungan sosial (Lyon, 2015). Adanya hubungan sosial yang baik dengan orang lain mendukung kesehatan jiwa yang lebih baik bagi individu.

Welas diri memiliki banyak manfaat bagi kesehatan jiwa individu. Hal tersebut menjadikan welas diri sebagai variabel yang banyak diteliti sejak konstruk ini pertama kali dicetuskan (Neff dkk., 2019). Alat ukur welas diri yang banyak digunakan dalam penelitian adalah Self-Compassion Scale (SCS) yang dikonstruksi oleh Neff (2003b). SCS telah diterjemahkan ke dalam banyak 
bahasa lain, setidaknya terdapat 17 terjemahan SCS dalam bahasa lain (Neff, 2019). Meskipun demikian, belum ada penelitian yang berfokus melakukan adaptasi terhadap SCS ke dalam Bahasa Indonesia. Oleh karena itu, penelitian ini bertujuan untuk meneliti kualitas psikometrik dan struktur faktor dari adaptasi Bahasa Indonesia SCS, yang peneliti terjemahkan menjadi Skala Welas Diri (SWD). Adaptasi SCS Bahasa Indonesia dapat mendorong perkembangan studi welas asih untuk mempromosikan kesehatan jiwa pada masyarakat Indonesia.

\section{Komponen Welas Diri}

Welas diri memiliki enam komponen yang saling berinteraksi dalam suatu sistem dinamis (Neff dkk., 2019). Komponen-komponen welas diri adalah sebagai berikut (Neff, 2003a; Neff, 2003b; Neff, Toth-Kiraly, \& Colosimo, 2018; Neff dkk., 2019):

Mengasihi diri vs. menghakimi diri (self-kindness vs. self-judgment). Welas diri terdiri dari sikap mengasihi diri yang tinggi dan sikap menghakimi diri yang rendah. Mengasihi diri ditunjukkan dengan sikap yang ramah, lembut, pengertian, dan penuh dukungan terhadap diri. Individu yang berwelas diri akan bersikap hangat dan menerima diri, serta tidak menghakimi diri sendiri atas penderitaan, kekurangan, dan kegagalan yang dialami.

Kemanusiaan universal vs. isolasi (common humanity vs. isolation). Welas diri terdiri dari kesadaran universal akan kemanusiaan yang tinggi dan rendahnya pemikiran bahwa ia terisolasi dari seluruh dunia ketika mengalami penderitaan. Kemanusiaan universal ditunjukkan dengan menyadari pengalaman universal manusia yang di dalamnya termasuk penderitaan, kegagalan, dan kesalahan. Kemanusiaan universal juga melibatkan kesadaran bahwa manusia sejatinya tidak sempurna. Individu yang berwelas diri melihat pengalaman penderitaan, kegagalan, dan kesulitan hidup dari banyak perspektif, sehingga tidak larut dalam perasaan bahwa hanya dirinya-lah yang gagal atau menderita.

Mindfulness vs. overidentifikasi (overidentification). Welas diri terdiri dari tingkat mindful yang tinggi dan tingkat ruminasi terhadap perasaan negatif (overidentifikasi) yang rendah. Kesadaran ditunjukkan dengan kejernihan dalam melihat bahwa individu sedang menderita tanpa terokupasi pada pemikiran dan perasaan bahwa ia menderita atau gagal.

Komponen-komponen welas diri merupakan konstruk yang berdiri secara independen, tetapi memengaruhi satu sama lain (Neff, 2016). Welas diri melihat respons emosional ketika mengalami penderitaan (lebih mengasihi dan tidak menghakimi), memahami secara kognitif kesulitan yang 
dialami (sebagai bagian dari kehidupan dan bukannya merasa sendirian dalam penderitaan), serta memerhatikan kesulitan (secara jernih tanpa larut dalam perasaan menderita; Neff dkk., 2019).

Komponen-komponen welas diri tersebut secara sinergis berinteraksi satu dengan yang lain membentuk sikap berwelas diri (Neff dkk., 2019). Komponen positif welas diri (mengasihi diri, kemanusiaan universal, dan mindfulness) yang tinggi disebut dengan istilah respons diri penuh welas asih (compassionate self-responding) dan komponen negatif welas diri (menghakimi diri, isolasi, dan overidentifikasi) yang rendah disebut berkurangnya respons diri yang berwelas asih (reduced uncompassionate self-responding; Neff dkk., 2019).

\section{Alat Ukur Welas Diri}

Welas diri diukur dalam beberapa instrumen penelitian. Compassion Scale (Pommier, 2010) dikonstruksi dengan konsep welas diri yang dikemukakan oleh Neff (2003b) untuk mengukur welas asih kepada diri dan orang lain. Gilbert dkk. (2017) juga mengonstruksi skala untuk mengukur welas asih, baik pada diri maupun orang lain. Alat ukur lain untuk welas diri adalah SelfCompassion Scale (SCS; Neff, 2003b) yang dikonstruksi berdasarkan definisi dan komponenkomponen welas asih oleh Neff (2003b; Neff, 2016; Neff dkk., 2019).

SCS merupakan alat ukur yang paling banyak digunakan dan paling sesuai dengan konsep welas diri yang dikemukakan pertama kali oleh Neff (2003a) dan melalui proses validasi berulang (Neff, 2016; Neff dkk., 2019). Compassion Scale ditemukan tidak memiliki korelasi dengan SCS (Pommier, 2010), meskipun dikonstruksi dengan konsep welas diri dari Neff (2003b). Sementara itu, skala welas asih yang dikonstruksi oleh Gilbert dkk. (2017) memiliki korelasi yang baik dengan SCS. Meskipun demikian, Gilbert dkk. (2017) mendefinisikan welas diri sebagai sikap meyakinkan diri yang menunjukkan kompetensi seseorang dalam berwelas asih, tetapi tidak melihat proses dinamis welas diri sesuai konseptualisasi dari Neff (Neff, 2003b; Neff dkk., 2019).

Penelitian ini hendak mengadaptasi SCS ke dalam Bahasa Indonesia. Ketika pertama kali diteliti konstruksinya, SCS menunjukkan kualitas psikometrik yang baik. SCS memiliki koefisien reliabilitas internal yang tinggi dengan nilai Cronbach's Alpha sebesar .92 dan kualitas butir yang baik (tiap subskala yang mengukur komponen welas diri memiliki koefisien .57 sampai dengan .80; Neff, 2003b). Penelitian ini hendak melihat kualitas psikometrik SCS Bahasa Indonesia dengan menggunakan metode yang sama, yaitu confirmatory factor analysis (CFA). SCS yang telah diadaptasi ke dalam Bahasa Indonesia akan diterjemahkan menjadi Skala Welas Diri (SWD). 


\section{METODE}

\section{Partisipan}

Partisipan penelitian adalah mahasiswa berusia 17-28 tahun yang berjumlah 329 orang $(M=$ 19.37; $S D=1.413$ ). Partisipan direkrut dengan convenience sampling dengan membagikan tautan skala daring pada tiap-tiap angkatan mahasiswa pada beberapa universitas di Jakarta dan sekitarnya. Sebanyak 261 partisipan $(79.33 \%)$ adalah perempuan, sementara 68 partisipan sisanya $(20.64 \%)$ adalah laki-laki.

\section{Desain}

Penelitian ini merupakan penelitian kuantitatif. Pada penelitian ini, welas diri didefinisikan sebagai sikap yang hangat, suportif, dan memahami diri ketika mengalami penderitaan atau kesulitan hidup. Welas diri juga merupakan sikap seseorang yang sadar bahwa penderitaan dan kesulitan hidup wajar dialami oleh semua manusia.

Skala Welas Diri (SWD) digunakan dalam penelitian ini dan merupakan adaptasi dari SelfCompassion Scale (SCS; Neff, 2003b). SWD terdiri dari 26 butir pernyataan yang mengukur keenam komponen welas diri dan menggunakan skala Likert dengan rentang angka 1 (Hampir Tidak Pernah) sampai 5 (Hampir Selalu). SWD menggunakan sistem skoring yang sama dengan SCS, di mana komponen negatif welas diri akan diskor terbalik. Rata-rata tiap komponen akan dihitung, kemudian dihitung rata-rata totalnya (grand mean). Cetak biru SWD dijelaskan dalam Tabel 1. 
Tabel 1.

Cetak Biru Skala Welas Diri

\begin{tabular}{|c|c|c|c|c|}
\hline \multirow[t]{2}{*}{ No } & \multirow[t]{2}{*}{ Komponen } & \multicolumn{2}{|c|}{ Nomor Butir } & \multirow[t]{2}{*}{ Jumlah Butir } \\
\hline & & Favorable & Unfavorable & \\
\hline 1 & $\begin{array}{l}\text { Mengasihi Diri } \\
\text { (Self-Kindness; SK) }\end{array}$ & $5,12,19,23,26$ & & 5 \\
\hline 2 & $\begin{array}{l}\text { Menghakimi Diri } \\
\text { (Self-Judgement; SJ) }\end{array}$ & & $1,8,11,16,21$ & 5 \\
\hline 3 & $\begin{array}{l}\text { Kemanusiaan Universal } \\
\text { (Common Humanity; } \mathrm{CH} \text { ) }\end{array}$ & $3,7,10,15$ & & 4 \\
\hline 4 & $\begin{array}{l}\text { Isolasi } \\
\text { (Isolation; I) }\end{array}$ & & $4,13,18,25$ & 4 \\
\hline 5 & Mindfulness (M) & $9,14,17,22$ & & 4 \\
\hline \multirow[t]{2}{*}{6} & $\begin{array}{l}\text { Overidentifikasi } \\
\text { (Overidentification; O) }\end{array}$ & & $2,6,20,24$ & 4 \\
\hline & & & Total & 26 \\
\hline
\end{tabular}

\section{Prosedur}

Penelitian dimulai dengan meninjau literatur mengenai welas diri dan pengukurannya. Setelah mendapatkan tinjauan teoretis mengenai konstruk welas diri dan pengukurannya berupa SCS, peneliti melakukan adaptasi skala menggunakan teknik terjemahan langsung dan balik (forward and backward translation; International Test Commission, 2017). Peneliti melakukan terjemahan langsung terhadap SCS dengan bantuan sarjana Sastra Inggris. Kemudian, peneliti melakukan tinjauan dan koreksi terhadap hasil-hasil terjemahan langsung. Setelah mendapatkan terjemahan yang dianggap paling kontekstual, peneliti melakukan terjemahan balik dengan bantuan seorang sarjana Psikologi lulusan universitas di Amerika Serikat dan juga penerjemah. Hasil dari proses terjemahan langsung dan balik menunjukkan kesesuaian makna antara hasil penerjemahan dengan bahasa aslinya.

Selanjutnya, peneliti mempersiapkan angket penelitian daring yang menyertakan informed consent dan kuesioner demografis. Setelah angket penelitian siap, peneliti menyebarkan angket penelitian kepada mahasiswa. Data yang didapat kemudian diolah dan dianalisa secara statistik.

\section{Teknik Analisis}

Teknik analisis yang digunakan dalam penelitian ini adalah confirmatory factor analysis (CFA). CFA merupakan metode evaluasi model pengukuran di mana model teoretis sebuah pengukuran dibandingkan dengan data (Brown, 2006). Beberapa indikator CFA digunakan untuk 
menentukan apakah pengukuran memiliki model teoretis yang didukung dengan data, seperti nilai RMSEA < .08, nilai CFI, IFI, NFI, dan TLI > .90, nilai GFI > .90, serta rasio $X^{2} / d f<2$ (Brown, 2006; Cangur \& Ercan, 2015; Schumaker \& Lomax, 2010). Selain CFA, koefisien korelasi butirtotal juga dihitung untuk melihat kesesuaian butir dengan konstruk yang diukur (Azwar, 2013). Validitas konstruk juga diuji lebih lanjut dengan melihat hubungan antara SWD dengan distres psikologis. Distres psikologis diukur dengan menggunakan skala Kessler 10 (K10; Kessler dkk., 2002) yang telah diterjemahkan ke dalam Bahasa Indonesia dari Transcultural Mental Health Centre (n.d.). Sementara itu, reliabilitas alat ukur dinilai berdasarkan koefisien Cronbach's Alpha.

\section{ANALISIS DAN HASIL}

Analisis faktor dilakukan terhadap SWD menggunakan teknik confirmatory factor analysis (CFA). CFA menguji model enam komponen SWD yang saling berkorelasi, yaitu Mengasihi Diri (Self-Kindness), Menghakimi Diri (Self-Judgment), Kemanusiaan Universal (Common Humanity), Isolasi (Isolation), Mindfulness, dan Overidentifikasi (Overidentification). Model ini sesuai dengan model awal yang dikonstruksi oleh Neff (2003b). Model enam komponen yang saling berkorelasi dan membentuk sistem dinamis ini juga ditemukan valid pada penelitian-penelitian di sampel yang berbeda (Neff, 2016; Neff dkk., 2019; Neff, Toth-Kiraly, \& Colosimo, 2018).

Berdasarkan hasil tes CFA, SWD memiliki kesesuaian model (model fit) yang cukup baik $\left(X^{2} / d f=1.324 ; \mathrm{RMSEA}=.043 ; \mathrm{GFI}=.910 ; \mathrm{CFI}=.935 ; \mathrm{TFI}=.923 ; \mathrm{NFI}=.848 ; \mathrm{IFI}=.936\right)$ dengan model yang diajukan oleh Neff (2003b). Hal ini ditunjukkan dengan beberapa indikator, yaitu nilai $X^{2} / d f$ yang kurang dari 2 , nilai RMSEA kurang dari .08, dan nilai GFI, CFI, TFI, dan IFI di atas .90 yang menunjukkan bahwa data cukup sesuai dengan model teoretis (Cangur \& Ercan, 2015; Schumaker \& Lomax, 2010). Indikator-indikator tersebut menunjukkan model yang cukup sesuai, meskipun nilai NFI di bawah 90 yang merupakan salah satu indikator kesesuaian model (Schumaker \& Lomax, 2010). Meskipun demikian, perlu dilakukan analisis evaluasi model lebih lanjut karena model mengalami modifikasi error sebanyak 12 kali.

CFA dua tingkat (second order CFA) dilakukan untuk melihat adanya faktor yang lebih tinggi dari keenam faktor SWD untuk menjustifikasi penggunaan skor total SWD. Hasil second order CFA menunjukkan model yang kurang sesuai $\left(X^{2} / d f=2.54\right.$; RMSEA $=.068$; GFI $=.853$; CFI $=.831 ; \mathrm{TFI}=.805)$. Neff (2016) mengajukan cara lain untuk menjustifikasi penggunaan skor total SCS, yaitu dengan model bifaktor di mana skor butir-butir SCS merepresentasikan keenam 
komponen welas diri, sekaligus welas diri secara keseluruhan. Hasil CFA bifaktor menunjukkan tingkat kesesuaian model ambang (marginal fit $X^{2} / d f=1.935 ;$ RMSEA $=.053$; GFI $=.893$; CFI $=$ .910 ; TFI = .882). Hal ini menunjukkan bahwa skor total SWD valid digunakan untuk mengukur tingkat welas diri.

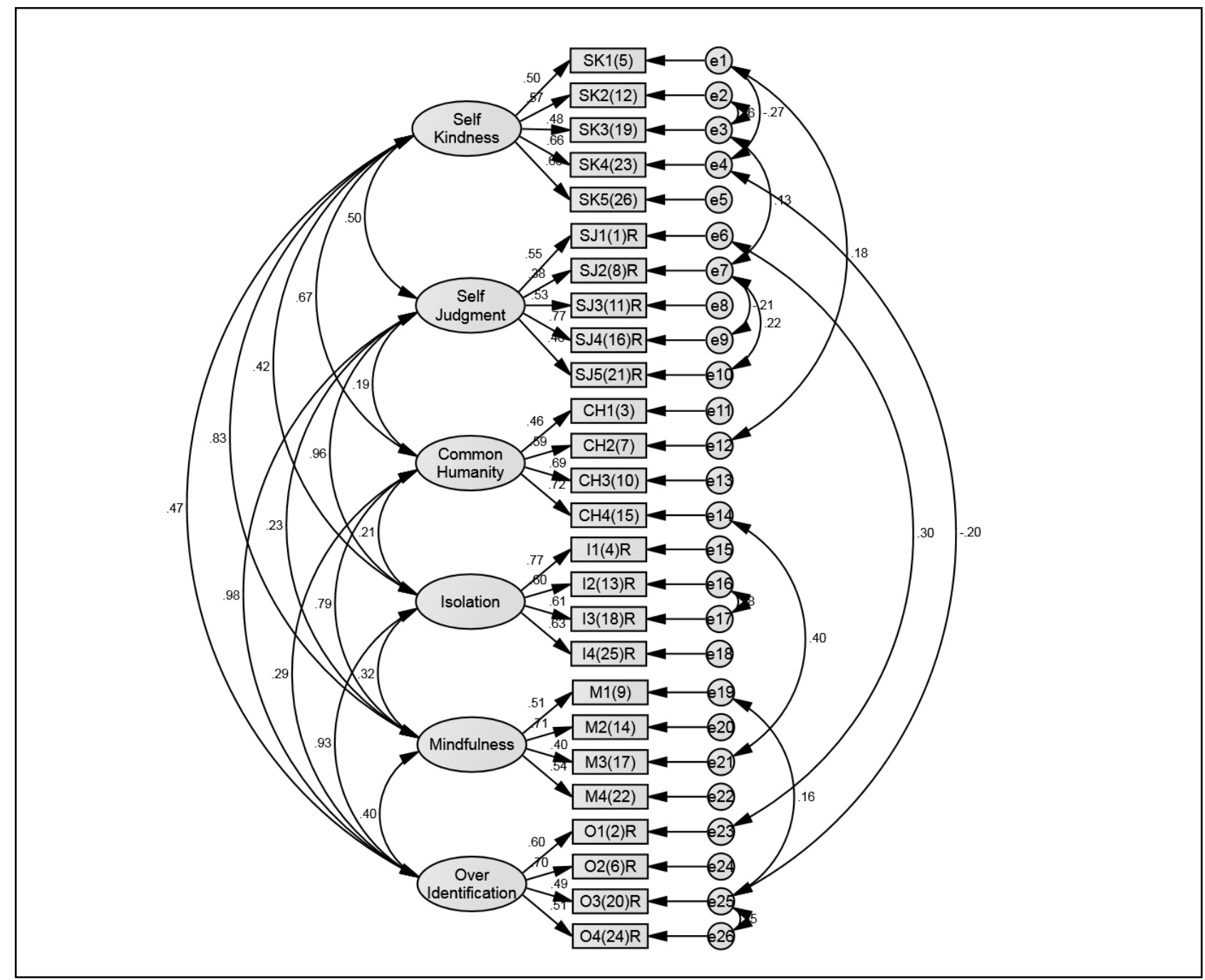

Figur 1. Model, Muatan Faktor, dan Interaksi Antar Komponen Skala Welas Diri

Butir-butir dalam SWD memiliki muatan faktor yang cukup memuaskan $(>.3, p<.01$; Brown, 2006). Selain itu, butir-butir SWD juga memiliki korelasi butir-total yang cukup baik, yaitu berkisar antara .26-.57. Indikator-indikator ini menunjukkan bahwa butir-butir SWD merepresentasikan welas diri dan komponen-komponennya. Selain itu, korelasi butir-total untuk tiap butir juga dianggap cukup baik, yaitu berkisar antara .21-.59. Hal ini mengindikasikan bahwa 
tiap butir SWD mengukur hal yang sama (Azwar, 2013). Ringkasan muatan faktor dan korelasi butir-total SWD tercantum dalam Tabel 2.

Tabel 2.

Hasil Analisis Validitas dan Reliabilitas Subskala Skala Welas Diri

\begin{tabular}{|c|c|c|c|c|c|c|}
\hline $\begin{array}{l}\text { No. } \\
\text { Butir }\end{array}$ & Deskripsi & AVE & MSV & $\alpha$ & $\mathbf{r}_{\mathrm{ix}}$ & MF \\
\hline \multicolumn{2}{|c|}{ Subskala Mengasihi Diri } & .36 & .70 & .71 & & \\
\hline 5 & $\begin{array}{l}\text { Saya mencoba untuk mencintai diri saya ketika saya } \\
\text { merasakan sakit secara emosional. }\end{array}$ & & & & .30 & .50 \\
\hline 12 & $\begin{array}{l}\text { Ketika saya mengalami waktu sulit, saya akan } \\
\text { memberikan kepedulian dan kelembutan yang saya } \\
\text { butuhkan. }\end{array}$ & & & & .47 & .57 \\
\hline 19 & $\begin{array}{l}\text { Saya baik terhadap diri saya saat mengalami } \\
\text { penderitaan. }\end{array}$ & & & & .40 & .48 \\
\hline 23 & $\begin{array}{l}\text { Saya bersikap toleran terhadap kelemahan dan } \\
\text { kekurangan saya. }\end{array}$ & & & & .55 & .66 \\
\hline 26 & $\begin{array}{l}\text { Saya mencoba untuk memahami dan bersabar pada } \\
\text { aspek-aspek kepribadian saya yang tidak saya sukai. }\end{array}$ & & & & .44 & .66 \\
\hline
\end{tabular}

Subskala Menghakimi Diri

$\begin{array}{lll}.31 & .97 \quad .69\end{array}$

1 Saya tidak menerima dan menghakimi kelemahan dan kekurangan saya.

8 Di waktu-waktu yang sangat sulit, saya cenderung bersikap keras pada diri saya.

11 Saya tidak toleran dan tidak sabar terhadap beberapa aspek kepribadian saya yang tidak saya sukai.

16 Ketika saya melihat aspek-aspek diri saya yang tidak saya sukai, saya merasa sedih pada diri saya.

21 Saya bisa bersikap tidak berperasaan pada diri saya saat mengalami penderitaan.

Subskala Kemanusiaan Universal

$3 \quad$ Ketika hal-hal buruk terjadi pada saya, saya melihat kesulitan hidup sebagai bagian hidup yang dilewati semua orang.

7 Ketika saya merasa sedih, saya mengingatkan diri saya bahwa ada banyak orang di dunia ini yang mengalami hal yang sama dengan saya.

$.39 \quad .63 \quad .72$

10 Ketika saya merasa merasa tidak mampu pada beberapa hal, saya mengingatkan diri saya bahwa perasaan tidak mampu juga dirasakan oleh sebagian besar orang.

15 Saya mencoba untuk melihat kegagalan saya sebagai bagian dari kondisi yang dialami manusia pada umumnya.

Subskala Isolasi

$\begin{array}{lll}.43 & .93 & .78\end{array}$

$4 \quad$ Ketika saya memikirkan kekurangan saya, hal tersebut akan membuat diri saya terkucil dari seisi dunia.

13 Ketika saya merasa sedih, saya cenderung merasa orang lain mungkin lebih bahagia dibandingkan saya. 


\begin{tabular}{|c|c|c|c|c|c|c|}
\hline $\begin{array}{l}\text { No. } \\
\text { Butir }\end{array}$ & Deskripsi & AVE & MSV & $\alpha$ & $\mathbf{r}_{\mathrm{ix}}$ & MF \\
\hline 18 & $\begin{array}{l}\text { Ketika saya sungguh menderita, saya cenderung merasa } \\
\text { bahwa orang lain lebih mudah dalam menjalani hidup. }\end{array}$ & & & & .51 & .61 \\
\hline 25 & $\begin{array}{l}\text { Ketika saya gagal pada hal yang penting bagi saya, } \\
\text { saya cenderung merasa sendiri di tengah-tengah } \\
\text { kegagalan tersebut. }\end{array}$ & & & & .51 & .63 \\
\hline \multicolumn{2}{|c|}{ Subskala Mindfulness } & .30 & .70 & .60 & & \\
\hline 9 & $\begin{array}{l}\text { Ketika sesuatu membuat saya kesal, saya berusaha } \\
\text { menjaga emosi saya tetap stabil. }\end{array}$ & & & & .31 & .51 \\
\hline 14 & $\begin{array}{l}\text { Ketika suatu hal menyakitkan terjadi, saya mencoba } \\
\text { untuk melihat situasi secara berimbang. }\end{array}$ & & & & .49 & .71 \\
\hline 17 & $\begin{array}{l}\text { Ketika saya gagal pada suatu hal yang penting bagi } \\
\text { saya, saya berusaha untuk melihatnya sebagai sesuatu } \\
\text { yang wajar. }\end{array}$ & & & & .34 & .40 \\
\hline 22 & $\begin{array}{l}\text { Ketika saya sedang terpuruk, saya mencoba } \\
\text { menanggapi perasaan saya dengan rasa ingin tahu dan } \\
\text { keterbukaan. }\end{array}$ & & & & .29 & .54 \\
\hline \multicolumn{2}{|r|}{ Subskala Overidentifikasi } & .34 & .97 & .68 & & \\
\hline 2 & $\begin{array}{l}\text { Ketika saya sedang terpuruk, saya cenderung terobsesi } \\
\text { dan terus terpaku pada segala hal vang salah. }\end{array}$ & & & & .53 & .60 \\
\hline 6 & $\begin{array}{l}\text { Ketika saya gagal pada suatu hal yang penting bagi } \\
\text { saya, saya larut dalam perasaan tidak mampu. }\end{array}$ & & & & .57 & .70 \\
\hline 20 & $\begin{array}{l}\text { Ketika suatu hal menjengkelkan terjadi, saya terbawa } \\
\text { perasaan. }\end{array}$ & & & & .34 & .49 \\
\hline 24 & $\begin{array}{l}\text { Ketika sesuatu yang menyakitkan terjadi, saya } \\
\text { cenderung membesar-besarkan kejadian tersebut. }\end{array}$ & & & & .42 & .51 \\
\hline
\end{tabular}

Keterangan: AVE = Average Variance Extracted $; \mathbf{M S V}=$ Maximum Shared Squared Variance $; \boldsymbol{\alpha}=$ Cronbach's alpha; $\mathbf{r}_{\mathbf{i x}}=$ korelasi butir total; $\mathbf{M F}=$ muatan faktor

Validitas konstruk SWD juga diuji dengan melihat korelasi antara SWD $(M=3.18, S D=$ .527) dengan skala yang mengukur distres psikologis, yaitu K10 $(M=26.872, S D=8.036)$. SWD memiliki korelasi negatif yang signifikan dengan $\mathrm{K} 10(r(327)=-.502, p<.001)$. Hal ini menunjukkan bahwa semakin tinggi welas asih dalam diri seseorang, maka semakin rendah distres psikologis yang dimiliki. Dengan demikian, SWD memenuhi kriteria validitas konstruk.

SWD juga dianalisis validitas konvergen dan diskriminannya dengan menghitung nilai AVE dan MSV (Hair, Black, Babin, \& Anderson, 2010). Hasil analisis menunjukkan bahwa keenam subskala welas diri memiliki validitas konvergen yang kurang baik, ditunjukkan dengan nilai AVE $<.5$ (Hair dkk., 2010). Selain itu, validitas diskriminan subskala welas diri juga kurang baik. Hal ini ditunjukkan dengan nilai MSV tiap subskala yang lebih besar dari AVE (Hair dkk., 2010).

Hasil uji reliabilitas SWD menunjukkan nilai Cronbach's Alpha sebesar .872 untuk keseluruhan SWD. Sementara itu, reliabilias komposit SWD yang ditinjau menggunakan 
MacDonald's $\omega$ menunjukkan nilai .873. Nilai reliabilitas untuk tiap subskala berkisar antara .60.78. Hal ini menunjukkan bahwa SWD memiliki reliabilitas yang cukup baik.

\section{DISKUSI}

Hasil analisis data menunjukkan bahwa SWD menunjukkan kesesuaian dengan model teoretis SCS yang dikembangkan oleh Neff (2003b). SCS terdiri dari enam komponen, yaitu Mengasihi Diri (Self-Kindness), Menghakimi Diri (Self-Judgment), Kemanusiaan Universal (Common Humanity), Isolasi (Isolation), Mindfulness, dan Overidentifikasi (Overidentification) yang merupakan konstruk-konstruk yang nyata berbeda (distinct), tetapi saling berkorelasi (Neff, 2003b; Neff dkk., 2019). Hal ini menunjukkan bahwa SWD memenuhi validitas konstruk, secara khusus validitas faktorial (Azwar, 2013).

Model enam komponen yang saling berkorelasi ini dianggap lebih merepresentasikan konseptualisasi welas diri (Neff, 2016; Neff, Toth-Kiraly, \& Colosimo, 2018). Model second order CFA di mana satu faktor tertinggi menaungi enam komponen di bawahnya tidak didukung pada penelitian ini. Meskipun demikian, penelitian ini menemukan kesesuaian ambang dengan model bifaktor, di mana butir-butir mengungkapkan adanya satu komponen laten utama dan enam komponen laten yang saling berkaitan. Hal ini mengonfirmasi penelitian sebelumnya yang menemukan bahwa SCS memiliki model teoretis bifaktor (Neff dkk., 2019; Neff, Toth-Kiraly, \& Colosimo, 2018). Dengan demikian, skor total SWD dapat digunakan untuk mengukur tingkat welas diri dalam diri seseorang.

Skor SWD memiliki korelasi negatif yang signifikan dengan skor K10. Hal ini berarti semakin tinggi tingkat welas diri pada diri seseorang, maka semakin rendah tingkat distres psikologisnya dan sebaliknya. Temuan ini konsisten dengan temuan dari penelitian sebelumnya yang menemukan bahwa welas diri berkaitan dengan tingkat distres, gejala depresif, dan gejala kecemasan yang lebih rendah (Marsh, Chan, \& Macbeth, 2017; Neff, 2003b; Soysa \& Wilcomb, 2013).

Indikator-indikator di atas menunjukkan bahwa SWD yang merupakan adaptasi Bahasa Indonesia dari SCS memiliki validitas konstruk yang baik. Selain itu, SWD juga memiliki reliabilitas yang cukup baik. Meskipun demikian, SWD menunjukkan validitas konvergen dan diskriminan yang kurang baik. Dengan demikian, SWD dapat digunakan sebagai alat ukur untuk mengukur welas diri, tetapi membutuhkan analisa lebih lanjut dengan sampel yang lebih beragam. 
SWD diadaptasi dan diuji pada sampel mahasiswa yang direkrut dengan convenience sampling. Pengujian SWD yang melibatkan partisipan dari berbagai daerah dan melibatkan sampel yang lebih representatif akan bermanfaat untuk melihat kualitas psikometrik SWD. Selain itu, pengujian SWD pada sampel lain dalam jumlah besar juga akan bermanfaat untuk mengevaluasi kecocokan model SWD dengan SCS.

\section{SIMPULAN DAN SARAN}

\section{Simpulan}

Adaptasi SCS ke dalam Bahasa Indonesia yang diberi nama SWD memiliki kualitas psikometrik yang cukup baik. Hasil CFA menunjukkan kesesuaian model yang cukup baik dengan teori. Selain itu, SWD juga memiliki reliabilitas yang baik.

\section{Saran Teoretis}

SWD ditemukan memiliki kualitas psikometrik yang cukup baik dan dapat digunakan dalam penelitian. Meskipun demikian, pada sampel penelitian ini SWD ditemukan memiliki validitas konvergen dan diskriminan yang kurang baik. Penelitian selanjutnya dapat menguji SWD dalam jumlah sampel yang lebih besar dan beragam untuk menghasilkan analisis psikometrik yang lebih akurat. Penelitian selanjutnya juga dapat menguji validitas konkuren dengan membandingkan SWD dengan alat ukur lain yang mengukur konstruk terkait welas diri. Dengan demikian, kualitas psikometrik SWD dapat semakin terbukti.

\section{Saran Praktis}

SWD dapat digunakan oleh peneliti yang tertarik untuk mengeksplorasi welas diri pada populasi yang berbahasa Indonesia. SWD juga dapat digunakan dalam penelitian intervensi yang bertujuan untuk meningkatkan welas diri, seperti dalam program Mindful Self-Compassion (MSC; Germer \& Neff, 2013). Intervensi yang berdasarkan pada konsep welas asih maupun welas diri juga dapat menggunakan SWD sebagai metode asesmen maupun evaluasi. 


\section{REFERENSI}

Azwar, S. (2013). Reliabilitas dan validitas (4th ed). Yogyakarta: Pustaka Pelajar.

Besser, A., \& Priel, B. (2011). Dependency, self-criticism and negative affect responses following imaginary rejection and failure threats: Meaning-making processes as moderators or mediators. Psychiatry, 74(1), 31-40.

Bloch, J. H. (2018). Self-compassion, social connectedness, and interpersonal competence (Master's thesis). University of Montana, Montana, United States.

Breines, J. G., \& Chen S. (2012). Self-compassion increases self-improvement motivation. Personal and Social Psychology Bulletin. Advance online publication. doi: $10.1177 / 0146167212445599$

Brown, T. A. (2006). Confirmatory factor analysis for applied research. New York, NY: The Guilford Press.

Cangur, S., \& Ercan, I. (2015). Comparison of model fit indices used in structural equation modelling under multivariate normality. Journal of Modern Applied Statistical Methods, 14(1), 152-167. doi: 10.22237/jmasm/1430453580

Cleare, S., Gumley, A., \& O’Connor, R. C. (2019). Self-compassion, self-forgiveness, suicidal ideation, and self-harm: A systematic review. Clinical Psychology and Psychotherapy. Advance online publication. doi: 10.1002/cpp.2372

Elices, M., Carmona, C., Pascual, J. C., Feliu-Soler, A., Martin-Blanco, A., \& Soler, J. (2017). Compassion and self-compassion: Construct and measurement. Mindfulness \& Compassion, 2, 34-40. doi: 10.1016/j.mincom.2016.11.003

Feldman, C., \& Kuyken, W. (2011). Compassion in the landscape of suffering. Contemporary Buddhism, 12(1). Advance online publication. doi: 10.1080/14639947.2011.564831

Germer, C. K., \& Neff, K. D. (2013). A pilot study and randomized controlled trial of the mindful self-compassion program. Journal of Clinical Psychology. Advance online publication. doi: $10.1002 /$ jclp.21923

Gilbert, P., Baldwin, M. W., Irons, C., Baccus, J. R., \& Palmer, M. (2006). Self-criticism and selfwarmth: An imagery study exploring their relation to depression. Journal of Cognitive Psychotherapy: An International Quarterly, 20(2), 183-200. 
Gilbert, P. Catarino, F., Duarte, C., Matos, M., Kolts, R., ... Basran, J. (2017). The development of compassionate engagement and action scales for self and others. Journal of Compassionate Health Care, 4(4). Advance online publication. doi: 10.1186/s40639-017-0033-3

Goetz, J. L., Keltner, D., \& Simon-Thomas, E. (2011). Compassion: An evolutionary analysis and empirical review. Psychological Bulletin, 136(3), 351-374. doi: 10.1037/a0018807

Hair, J., Black, W., Babin, B., \& Anderson, R. (2010). Multivariate data analysis (7th ed.). Upper Saddle River, NJ: Prentice-Hall.

International Test Commission. (2017). ITC guidelines for translating and adapting tests (second edition). International Journal of Testing. doi: 10.1080/15305058.2017.1398166.

Joeng, J. R., \& Turner, S. L. (2015). Mediators between self-criticism and depression: Fear of compassion, self-compassion, and importance to others. Journal of Counseling Psychology. Advance online publication. doi: 10.1037/cou0000071

Kannan, D., \& Levitt, H. M. (2013). A review of client self-criticism in psychotherapy. Journal of Psychotherapy Integration, 23(2), 166-178. doi: 10.1037/a0032355

Kessler, R. C., Andrews, G., Colpe, L. J., Hiripi, E., Mroczek, D. K., Normand, S. L. T., Walters, E. E., \& Zaslavsky, A. M. (2002). Short screening scales to monitor population prevalences and trends in non-specific psychological distress. Psychological Medicine, 32, 959-976. doi: $10.1017 / \mathrm{S} 0033291702006074$

Leary, M. R., Tate, E. B., Adams, C. E., Allen, A. B., \& Hancock, J. (2007). Self-compassion and reactions to unpleasant self-relevant events: The implications of treating oneself kindly. Personality Processes and Individual Differences, 92(5), 887-904. doi: 10.1037/00223514.92.5.887

Lyon, T. (2015). Self-compassion as a predictor of loneliness: The relationship between selfevaluation processes and perceptions of social connection (Selected honor theses). Southeastern University, Florida, United States.

Marsh, I. C., Chan, S. W. Y., \& Macbeth, A. (2017). Self-compassion and psychological distress in adolescents: A meta-analysis. Mindfulness, 9, 1011-1027. doi: 10.1007/s12671-017-0850-7

Neff, K. D. (2003a). Self-compassion: An alternative conceptualization of a healthy attitude toward oneself. Self and Identity, 2, 85-101. doi: 10.1080/15298860390129863

Neff, K. D. (2003b). The development and validation of a scale to measure self-compassion. Self and Identity, 2, 223-250. doi: 10.1080/15298860390209035 
Neff, K. D. (2011). Self-compassion, self-esteem, and well-being. Social and Personality Psychology Compass, 5(1). Advance online publication. doi: 10.1111/j.17519004.2010.00330.x

Neff, K. D. (2016). The Self-Compassion Scale is a valid and theoretically coherent measure of self-compassion. Mindfulness. Advance online publication. doi: 10.1007/s12671-015-04793

Neff, K. D. (2019). Self-compassion scales. SELF-COMPASSION. Ditemu kembali dari https://self-compassion.org/self-compassion-scales-for-researchers/

Neff, K. D., \& Seppala, E. (2016). Compassion, well-being, and the hypoegoic self. Dalam K. W. Brown \& M. Leary (Eds.), Oxford handbook of hypo-egoic phenomena: Theory and research on the quiet ego (hlm. 478-497). United Kingdom, UK: Oxford University Press.

Neff, K. D., Toth-Kiraly, I., \& Colosimo, K. (2018). Self-compassion is a global construct and is overlapping with but distinct from neuroticism: A response to Pfattheicher, Geiger, Hartung, Weiss, and Schindler (2017). European Journal of Personality, 32, 371-392. doi: 10.1002/per. 2148

Neff, K. D., Toth-Kiraly, I., Yarnell, L. M., Arimitsu, K., Castilho, P., .. Mantzios, M. (2019). Examining the factor structure of the Self-Compassion Scale in 20 diverse samples: Support for use of a total score and six subscale scores. Psychological Assessment, 31(1), 27-45. doi: 10.1037/pas0000629

Pommier, E. A. (2010). The compassion scale (Doctoral dissertation). The University of Texas at Austin, Texas, United States.

Schumaker, R. E., \& Lomax, R. G. (2010). A beginner's guide to structural equation modeling (3rd ed). New York, NY: Routledge.

Soysa, C. K., \& Wilcomb, C. J. (2013). Mindfulness, self-compassion, self-efficacy, and gender as predictors of depression, anxiety, stress, and well-being. Mindfulnes. Advance online publication. doi: 10.1007/s12671-013-0247-1

Transcultural Mental Health Service. (n.d.). Kessler 10. Ditemu kembali dari https://www.dhi.health.nsw.gov.au/transcultural-mental-health-centretmhc/resources/multilingual-resources-by-title/kessler10 ? Paging Module=883\&retain=true $\&$ pg $=2$. 